Article

\title{
Characteristics of Precipitation of Rare Earth Elements with Various Precipitants
}

\author{
Kenneth N. Han
}

South Dakota School of Mines and Technology, Rapid City, SD 57701-3995, USA; kennethhydro@gmail.com

Received: 7 January 2020; Accepted: 11 February 2020; Published: 17 February 2020

\begin{abstract}
The effective and selective leaching of rare earth elements (REEs) from various sources is frequently possible in practice by adopting a carefully coordinated strategy incorporating a selective precipitation of these elements from undesired ones in solution. In this study, the behavior of chemical precipitation of REEs with commonly used precipitants such as sulfate, carbonate, fluoride, phosphate, and oxalate was examined using thermodynamic principles and calculations. It was found that the $\mathrm{pH}$ of the system has a profound effect on determining particular chemical species of precipitants, which are subsequently responsible for the precipitation of REEs. The role of various anions such as $\mathrm{Cl}^{-}, \mathrm{NO}_{3}{ }^{-}$, and $\mathrm{SO}_{4}{ }^{2-}$ derived from the acid used in the leaching process on the precipitation behavior of REEs was examined. These anions form complexes with REEs and display a very positive effect on the precipitation behavior. The nitrate environment exhibits most conducive to precipitation followed by sulfate and then chloride.
\end{abstract}

Keywords: precipitation; leaching; complexation; anion effect; equilibrium calculation; rare earth elements

\section{Introduction}

Rare earth elements (REEs) are becoming very important in modern society. REEs are essential ingredients in the transition to green technology and there have been numerous recent articles describing their extraction processes from various sources [1,2].

Most rare earth bearing minerals are refractory in nature and therefore, a pretreatment or strong acid treatment of ores bearing these minerals is usually necessary [3-6] before leaching is affected. Such pretreated ores are then subjected to the leaching process of REEs. The leach liquor is frequently subjected to the removal of impurities such as iron, calcium, uranium, and thorium by going through stage-wise precipitation using various compounds such as hydroxide, carbonate, sulfate, and oxalate [7-13]. After the removal of these impurities by chemical precipitation, REEs in solution are then subjected to precipitation using various precipitants, which in general takes place at $\mathrm{pH}$ above 3-4, since most of these impurities are precipitated at around these pHs. However, during the precipitation of impurities, some REEs are also removed from the solution by coprecipitation or adsorption. Therefore, it is desirable to precipitate REEs before removal of the impurities. It is the hope of this study to identify the precipitants and chemical conditions to achieve this objective.

The chemical complexity of the aqueous medium introduced by various chemical treatment of leach liquor has introduced a complex nature to the system making the analysis of the subsequent chemical precipitation a challenge. In addition to metal ions in the leach liquor extracted from ores, many anions such as $\mathrm{Cl}^{-}, \mathrm{NO}_{3}{ }^{-}$, and $\mathrm{SO}_{4}{ }^{2-}$ mostly derived from acids used in the leaching operation also play an important role in leaching as well as precipitation.

The effect of various anions on the leaching behavior has been discussed in earlier studies [14,15]. For example, the leaching of Re-phosphate in the presence of sulfuric acid can be simply described by 
Equation (1). (It is noted that Re is the elemental symbol for rhenium. However, Re(III) refers to only REE(III) in this paper.)

$$
<\mathrm{RePO}_{4}>+\left\{\mathrm{H}_{2} \mathrm{SO}_{4}\right\}=\left\{\mathrm{Re}^{3+}\right\}+\left\{\mathrm{PO}_{4}{ }^{3-}\right\}+\left\{\mathrm{SO}_{4}{ }^{2-}\right\}+2\left\{\mathrm{H}^{+}\right\}
$$

Here the symbols, $<>$ and \{\} stand for solid and liquid form, respectively. The oxidation state of REEs in solution and solids is assumed to be Re(III) throughout this presentation. It should be noted however, that some REEs can be oxidized to $\operatorname{Re}(\mathrm{IV})$ or reduced to $\operatorname{Re}(\mathrm{II})$ in aqueous media in very rare cases [16]. The concentration of the free REEs at equilibrium can be estimated if the concentration of all species involved in Equation (1) is known. However, such calculated values are far from real values since the chemicals produced from the leaching process undergo hydrolysis and complexation [14,15]. As a result, the correct evaluation of the product concentration requires a very complicated process involving calculations of equilibrium equations simultaneously in some cases.

The chemical precipitation of REEs is similarly complicated. For example, a simple chemical precipitation of a free Re-ion, $\mathrm{Re}^{3+}$ with phosphate ion, $\mathrm{PO}_{4}{ }^{3-}$ can be given by Equation (2).

$$
\left\{\operatorname{Re}^{3+}\right\}+\left\{\mathrm{PO}_{4}{ }^{3-}\right\}=<\mathrm{RePO}_{4}>
$$

It should be noted that REEs precipitate with the phosphate ion as a free $\mathrm{Re}-\mathrm{ion}, \mathrm{Re}^{3+}$ at relatively high $\mathrm{pHs}$ such as 4 and 6 . However, when the $\mathrm{pH}$ of the solution changes to a lower value, for example 1 or 2, by adding acids of $\mathrm{HCl}, \mathrm{HNO}_{3}$, or $\mathrm{H}_{2} \mathrm{SO}_{4}$, the anions such as $\mathrm{Cl}^{-}, \mathrm{NO}_{3}{ }^{-}$, and $\mathrm{SO}_{4}{ }^{2-}$ will form various complexes with REEs $[3,14,15]$, and then these complexes are subjected to precipitation. For example, in the presence of sulfate ions, there will be at least $\operatorname{Re}^{3+}, \operatorname{Re}\left(\mathrm{SO}_{4}\right)^{+}, \operatorname{Re}\left(\mathrm{SO}_{4}\right)_{2}{ }^{-}$, and $\mathrm{Re}_{2}\left(\mathrm{SO}_{4}\right)_{3}$, present in solution, and for most of the sulfate concentration, $\operatorname{Re}\left(\mathrm{SO}_{4}\right)_{2}{ }^{-}$is the predominant species when the concentration of sulfate ions is especially more than $0.1 \mathrm{M}[14,15]$. As a result, in such cases, $\operatorname{Re}\left(\mathrm{SO}_{4}\right)_{2}{ }^{-}$should be used instead of the free ion and the resulting concentration of rare earth elements after precipitation is an order of magnitude different from when the free ion is used.

In addition, the phosphate ion also may not exist depending upon the $\mathrm{pH}$ of the system. It should be noted that the values of $\mathrm{pKa}$ are 2.0 for $\mathrm{H}_{3} \mathrm{PO}_{4} / \mathrm{H}_{2} \mathrm{PO}_{4}{ }^{-}, 7.2$ for $\mathrm{H}_{2} \mathrm{PO}_{4}{ }^{-} / \mathrm{HPO}_{4}{ }^{2-}$, and 12.0 for $\mathrm{HPO}_{4}{ }^{2-} / \mathrm{PO}_{4}{ }^{3-}$ (see Table 1) [17]. This means that $\mathrm{H}_{3} \mathrm{PO}_{4}$ should be used instead of the phosphate ion in Equation (2) for the system whose $\mathrm{pH}$ lies below 2 and likewise, $\mathrm{H}_{2} \mathrm{PO}_{4}^{-}$for $\mathrm{pH}$ between 2 and 7.2 and so on.

Table 1. The pKa values for various precipitants [17].

\begin{tabular}{cc}
\hline Precipitants & pKa \\
\hline $\mathrm{H}_{3} \mathrm{PO}_{4} / \mathrm{H}_{2} \mathrm{PO}_{4}{ }^{-}$ & 2.1 \\
$\mathrm{H}_{2} \mathrm{PO}_{4}{ }^{-} / \mathrm{HPO}_{4}{ }^{2-}$ & 7.2 \\
$\mathrm{HPO}_{4}{ }^{2-} / \mathrm{PO}_{4}{ }^{3-}$ & 12.0 \\
$\mathrm{H}_{2} \mathrm{CO}_{3} / \mathrm{HCO}_{3}{ }^{-}$ & 6.38 \\
$\mathrm{HCO}_{3}{ }^{-} / \mathrm{CO}_{3}{ }^{2-}$ & 10.34 \\
$\mathrm{HF}^{-} / \mathrm{F}^{-}$ & 3.0 \\
$\mathrm{H}_{2} \mathrm{C}_{2} \mathrm{O}_{4} / \mathrm{HC}_{2} \mathrm{O}_{4}^{-}$ & 1.0 \\
$\mathrm{HC}_{2} \mathrm{O}_{4}{ }^{-} / \mathrm{C}_{2} \mathrm{O}_{4}{ }^{2-}$ & 4.2 \\
$\mathrm{HSO}_{4}^{-} / \mathrm{SO}_{4}{ }^{2-}$ & 2.0 \\
\hline
\end{tabular}

In this paper, factors such as $\mathrm{pH}$, complexation, and hydration of precipitants affecting the chemical precipitation with various precipitants will be examined and their practical implication in the analysis of such precipitation processes will be discussed. The precipitation behavior of REEs with carbonate, fluoride, phosphate, sulfate, and oxalate was considered in this study, since these precipitants are most widely used in precipitation of REEs in practice. 


\section{Acquisition of Thermodynamic Information}

Table 1 presents the values of pKa for the precipitants considered in this study. It should be noted that there are some variations in the numerical values of $\mathrm{pKa}$ based on various literature sources. For example, the values for oxalic acid given by Pourbaix [17] and Dean [18] are different from those by HSC [19] and Wagman [20]. However, the effect of such differences on the final outcome of the behavior of chemical precipitation is not very significant.

The thermodynamic data used in this study are listed in Table 2. Most data given in the table were taken from the literature information [21-26] and those unavailable were estimated using the parallel plot method as described earlier [14].

Table 2. The Gibbs standard free energy formation of various compounds in $\mathrm{kCal} / \mathrm{mol}$. Information taken from $[14,15]$ with some modifications.

\begin{tabular}{ccccccc}
\hline & Carbonate & Phosphate & Sulfate & Fluoride & Oxalate & Oct-Sulfate \\
\hline $\mathrm{La}$ & -768.5 & -455.3 & -892.6 & -399.8 & -872.2 & -1399.9 \\
$\mathrm{Ce}$ & -761.4 & -455.2 & -884.7 & -396.8 & -868.3 & -1340.2 \\
$\mathrm{Pr}$ & -764.5 & -451.0 & -879.4 & -394.2 & -860.6 & -1343.5 \\
$\mathrm{Nd}$ & -761.6 & -448.7 & -877.2 & -391.5 & -861.8 & -1335.0 \\
$\mathrm{Sm}$ & -759.6 & -447.6 & -878.8 & -392.3 & -860.1 & -1330.5 \\
$\mathrm{Eu}$ & -759.4 & -446.7 & -875.3 & -391.0 & -859.1 & -1275.3 \\
$\mathrm{Gd}$ & -758.6 & -445.5 & -874.2 & -390.5 & -857.7 & -1328.1 \\
$\mathrm{~Tb}$ & -757.0 & -444.7 & -873.7 & -388.7 & -856.9 & -1313.2 \\
$\mathrm{Dy}$ & -750.6 & -442.2 & -868.9 & -385.9 & -856.0 & -1323.3 \\
$\mathrm{Ho}$ & -744.2 & -440.4 & -861.3 & -383.0 & -849.6 & -1314.3 \\
$\mathrm{Er}$ & -743.9 & -439.1 & -855.9 & -380.9 & -842.0 & -1309.5 \\
$\mathrm{Tm}$ & -736.9 & -438.2 & -862.9 & -379.6 & -846.6 & -1308.1 \\
$\mathrm{Yb}$ & -735.5 & -437.6 & -861.5 & -378.4 & -839.5 & -1293.4 \\
$\mathrm{Lu}$ & -734.5 & -435.7 & -860.1 & -376.8 & -841.3 & -1319.1 \\
$\mathrm{Y}$ & -749.9 & -443.0 & -866.8 & -389.4 & -851.5 & -1320.6 \\
$\mathrm{Sc}$ & -714.9 & -418.2 & -845.1 & -361.5 & -828.4 & -1300.0 \\
\hline \multicolumn{5}{c}{ Oct-sulfate: $\mathrm{Re}_{2}\left(\mathrm{SO}_{4}\right)_{3} \cdot 8 \mathrm{H}_{2} \mathrm{O}$ (here Re represents REEs). }
\end{tabular}

Some of the standard Gibbs free energy formation values, such as Y-and Sc-oxalates were not available in the literature and, therefore, were estimated using the parallel method as described by earlier studies $[14,15]$. It should be noted that there were typographical errors in the values for Re-octa-hydrated sulfates in earlier publications $[14,15]$. It should also be noted that subsequent relevant calculations in the same articles were carried out using correct values, however.

\section{Carbonate System}

It is well known that rare earth elements are readily precipitated with carbonate at high pHs. Rare earth elements are readily subjected to precipitation with carbonate $[27,28]$ especially at high pHs. Re-carbonates are ideal precipitates, since carbonates are readily available, relatively less expensive than other precipitants, and precipitates can be easily dissolved in a mild acid for further treatments of REEs in subsequent processes of purification. However, it is not easily precipitated in acidic media. As a result, the leach liquor is usually subjected to a neutralization step before the precipitation of REEs with carbonate is affected. During the neutralization process, however, impurities such as $\mathrm{Fe}^{3+}$, $\mathrm{Ca}^{2+}$ are precipitated first resulting in loss of REEs due to adsorption and coprecipitation of REEs with oxides or sulfates of impurities.

A simple stoichiometric equation describing the precipitation of REEs with carbonate can be written in Equation (3), which is analogous to Equation (2).

$$
2\left\{\operatorname{Re}^{3+}\right\}+3\left\{\mathrm{CO}_{3}{ }^{2-}\right\}=<\operatorname{Re}_{2}\left(\mathrm{CO}_{3}\right)_{3}>
$$


As discussed earlier, the concentration of $\mathrm{CO}_{3}{ }^{2-}$ at $\mathrm{pH}$ 1-6 that was considered in this study, which is consistent with the range of $\mathrm{pH}$ practiced in industry, is practically zero, since the $\mathrm{pK}$ value for $\mathrm{HCO}_{3}{ }^{-} / \mathrm{CO}_{3}{ }^{2-}$ is 10.34 . The stable species at $\mathrm{pH}$ less than 6 , is $\mathrm{H}_{2} \mathrm{CO}_{3}$, which is the dominant species as seen in Table 1 and, therefore, $\mathrm{H}_{2} \mathrm{CO}_{3}$ should be used in Equation (3). Furthermore, when $\mathrm{pH}$ of the solution is less than $6, \mathrm{Re}^{3+}$ is subjected to complexation to become either $\operatorname{ReCl}{ }^{2+}, \operatorname{Re}\left(\mathrm{NO}_{3}\right)^{2+}$, or $\mathrm{Re}\left(\mathrm{SO}_{4}\right)_{2}{ }^{-}$depending upon the kind of acid used $[14,15]$. Therefore, for the working $\mathrm{pH}$ range (pH 1-6) in this study, Equations (4)-(6) should be used for chloride, nitrate, and sulfate systems instead of Equation (3).

$$
\begin{gathered}
2\left\{\operatorname{ReCl}^{2+}\right\}+3\left\{\mathrm{H}_{2} \mathrm{CO}_{3}\right\}=<\operatorname{Re}_{2}\left(\mathrm{CO}_{3}\right)_{3}>+2\left\{\mathrm{Cl}^{-}\right\}+6\left\{\mathrm{H}^{+}\right\} \\
2\left\{\operatorname{Re}\left(\mathrm{NO}_{3}\right)^{2+}\right\}+3\left\{\mathrm{H}_{2} \mathrm{CO}_{3}\right\}=<\operatorname{Re}_{2}\left(\mathrm{CO}_{3}\right)_{3}>+2\left\{\mathrm{NO}_{3}{ }^{-}\right\}+6\left\{\mathrm{H}^{+}\right\} \\
2\left\{\operatorname{Re}\left(\mathrm{SO}_{4}\right)_{2}{ }^{-}\right\}+3\left\{\mathrm{H}_{2} \mathrm{CO}_{3}\right\}=<\operatorname{Re}_{2}\left(\mathrm{CO}_{3}\right)_{3}>+4\left\{\mathrm{SO}_{4}{ }^{2-}\right\}+6\left\{\mathrm{H}^{+}\right\}
\end{gathered}
$$

In order to illustrate the steps involved in calculating the equilibrium concentration of REEs in solution, let us take Equation (4) as an example. The equilibrium constant for Equation (4), $\mathrm{K}_{\text {eq }}$ can be found knowing the Gibbs standard free energy formation of each component involved in the reaction. Such found equilibrium constant is given in Equation (7) below:

$$
\mathrm{K}_{\mathrm{eq}}=\frac{\left\{\mathrm{Cl}^{-}\right\}^{2}\left\{\mathrm{H}^{+}\right\}^{6}}{\left\{\mathrm{ReCl}^{2+}\right\}^{2}\left\{\mathrm{H}_{2} \mathrm{CO}_{3}\right\}^{3}}
$$

Here $\left\{\mathrm{H}^{+}\right\}$is known if the $\mathrm{pH}$ of the system is known, $\left\{\mathrm{Cl}^{-}\right\}$is known since the $\mathrm{pH}$ of the system is adjusted by $\mathrm{HCl}$ in this reaction, (see Table 3 ) and $\left\{\mathrm{H}_{2} \mathrm{CO}_{3}\right\}$ was set as $10^{-4} \mathrm{M}$. Therefore, $\left\{\mathrm{ReCl}^{2+}\right\}$ can be determined.

It should be noted that Equation (6) is valid above $\mathrm{pH} 2$ but $\mathrm{SO}_{4}{ }^{2-}$ should be replaced by $\mathrm{HSO}_{4}{ }^{-}$ when the $\mathrm{pH}$ of the system is less than 2 (See Table 3). When Equations (4)-(6) are solved to calculate the equilibrium concentrations of REEs in solution, it was assumed that the final concentrations of $\mathrm{Cl}^{-}$, $\mathrm{NO}_{3}{ }^{-}$, and $\mathrm{SO}_{4}{ }^{2-}$ are those set by respective acid concentration to adjust the $\mathrm{pH}$ of the solution as discussed above. This assumption is reasonable for low $\mathrm{pHs}$ but the accurate estimation of the final equilibrium concentrations of REEs at $\mathrm{pH} 6$ should be carried out taking into account all of practical conditions of the system.

It should also be noted that most of precipitants considered here are mostly weak acids and, therefore, they contribute in setting the $\mathrm{pH}$ of the solution (see Table 4). This can be a cause of inaccuracy in the final results especially at relatively high $\mathrm{pHs}$, say $\mathrm{pH}$ greater than 4 . The correction of such effects can be made but no attempt on such corrections was made in this study. This is because the objective of the study is to observe the precipitation behavior at low $\mathrm{pHs}$.

Table 3. Concentrations of various anions used in the study at different $\mathrm{pH}^{\prime} \mathrm{s}$ [17].

\begin{tabular}{ccclc}
\hline & $\mathbf{H C l}$ & $\mathrm{HNO}_{3}$ & \multicolumn{2}{c}{$\mathbf{H}_{2} \mathbf{S O}_{4}$} \\
\hline $\mathrm{pH}$ & $\mathrm{Cl}^{-}(\mathrm{M})$ & $\mathrm{NO}_{3}{ }^{-}(\mathrm{M})$ & $\mathrm{SO}_{4}{ }^{2-}(\mathrm{M})$ & $\mathrm{HSO}_{4}{ }^{-}(\mathrm{M})$ \\
6 & $1.0 \times 10^{-6}$ & $1.0 \times 10^{-6}$ & $1.0 \times 10^{-6}$ & $9.9 \times 10^{-11}$ \\
5 & $1.0 \times 10^{-5}$ & $1.0 \times 10^{-5}$ & $1.0 \times 10^{-5}$ & $9.9 \times 10^{-9}$ \\
4 & $1.0 \times 10^{-4}$ & $1.0 \times 10^{-4}$ & $9.9 \times 10^{-5}$ & $9.9 \times 10^{-7}$ \\
3 & $1.0 \times 10^{-3}$ & $1.0 \times 10^{-3}$ & $9.1 \times 10^{-4}$ & $9.0 \times 10^{-5}$ \\
2 & $1.0 \times 10^{-2}$ & $1.0 \times 10^{-2}$ & $5.0 \times 10^{-3}$ & $5.0 \times 10^{-3}$ \\
1 & $1.0 \times 10^{-1}$ & $1.0 \times 10^{-1}$ & $9.0 \times 10^{-3}$ & $9.1 \times 10^{-2}$ \\
0 & 1.0 & 1.0 & $1.0 \times 10^{-2}$ & $9.9 \times 10^{-1}$ \\
\hline
\end{tabular}


Table 4. The $\mathrm{pH}$ values of some weak acids for various concentrations.

\begin{tabular}{ccccc}
\hline Concentration, $\mathbf{M}$. & $\mathbf{H}_{3} \mathbf{P O}_{4}$ & $\mathbf{H F}$ & $\mathbf{H}_{\mathbf{2}} \mathbf{C O}_{3}$ & $\mathbf{H}_{\mathbf{2}} \mathbf{C}_{\mathbf{2}} \mathbf{O}_{4}$ \\
\hline $1.0 \times 10^{-6}$ & 5.97 & 6 & 6.31 & 6 \\
$1.0 \times 10^{-4}$ & 4 & 4.05 & 5.2 & 4 \\
$1.0 \times 10^{-3}$ & 3 & 3.26 & 4.69 & 3 \\
$1.0 \times 10^{-2}$ & 2.3 & 2.64 & 4.18 & 2.09 \\
$1.0 \times 10^{-1}$ & 1.63 & 2.1 & 3.68 & 1.31 \\
\hline
\end{tabular}

It is important to note that any calculated value exceeding the highest concentration of REEs in practice should be treated with caution. The highest concentration of REEs possible in the aqueous system is based on the grade of REEs in the ore being leached. Assuming the highest grade of REEs of the ore being treated is $50 \%$, the highest concentration of REEs possible in the aqueous media could be about $1.5 \mathrm{M}$ [15]. It is safe to assume that when the calculated value is more than 1-2 M, the precipitation is impossible under the conditions considered. On the other hand, when the calculated value is less than the target value, $1 \mathrm{ppm}$, then the precipitation could be favorable.

Figure 1 presents the equilibrium concentration of dissolved REEs in solution when REEs are subjected to precipitation with carbonate. In this study, the concentration of the precipitant, was kept constant at $10^{-4} \mathrm{M}$ throughout the paper as stated earlier. The choice of the precipitant concentration being $10^{-4} \mathrm{M}$, which is the final concentration after the precipitation is completed, is arbitrary and deemed reasonable in view of practical application. The horizontal dashed line across the figure represents the concentration of REEs in solution being $3 \times 10^{-6} \mathrm{M}$, which is about 1 ppm of REEs. This is an arbitrary concentration representing an acceptable target level of precipitation of REEs after subjecting to the carbonate precipitation.

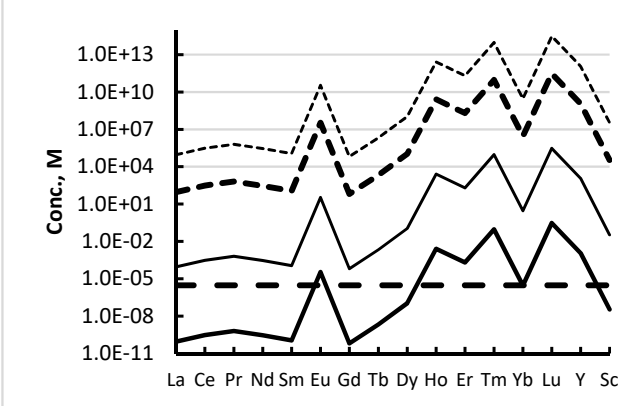

(a)

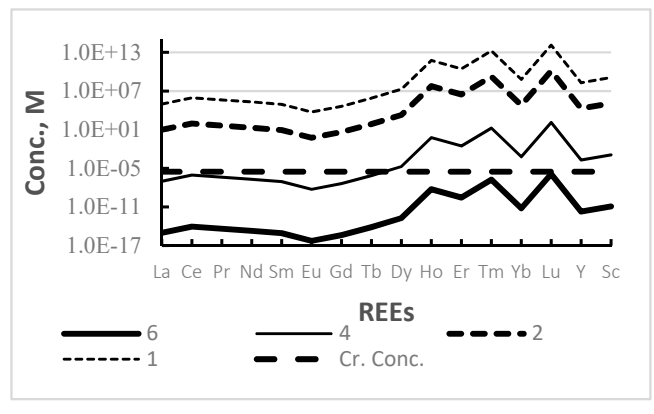

(c)

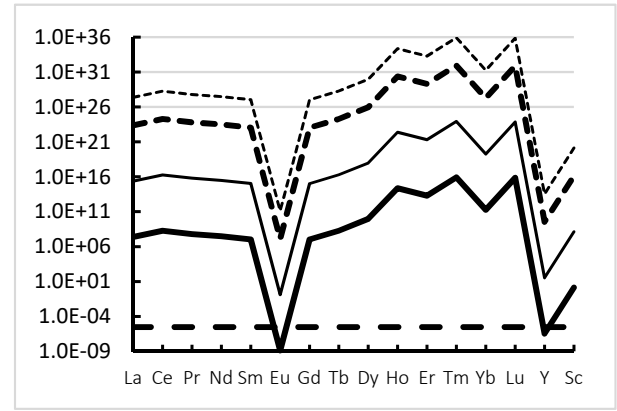

(b)

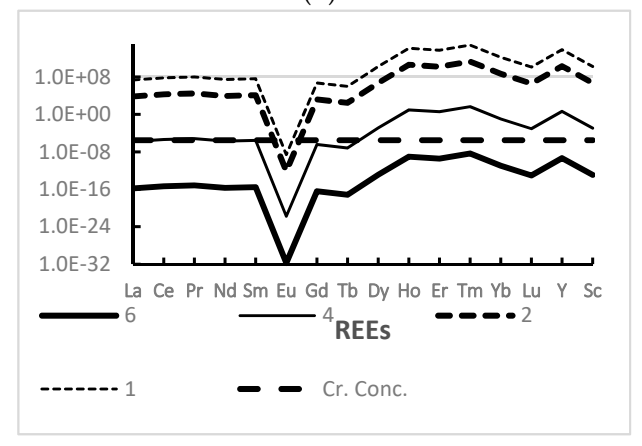

(d)

Figure 1. Concentrations of (a) $\operatorname{Re}^{3+},(\mathbf{b}) \mathrm{ReCl}_{2}{ }^{+}$, (c) $\operatorname{Re}\left(\mathrm{NO}_{3}\right)_{2}{ }^{+}$, and (d) $\operatorname{Re}\left(\mathrm{SO}_{4}\right)_{2}{ }^{-}$in equilibrium with carbonate precipitate with $10^{-4} \mathrm{M}$ of total concentration of carbonate in solution at $\mathrm{pH} 6,4,2$, and 1 . Cr.concentration: 1 ppm line as a target concentration.

It is a reasonable assumption that the initial concentration of REEs in the leach liquor would be in the range of $3 \times 10^{-1}$ to $3 \times 10^{-3} \mathrm{M}$ [15]. It is a usual practice that the initial concentration of the 
precipitant is a little more than the stoichiometric amount. It is obvious that carbonate is incapable of precipitating most of REEs, except a few light REEs at $\mathrm{pH}$ 6. It is interesting to note that the precipitation of nitrate and sulfate complexes is significantly better than free REE ions. The anomaly behavior by Eu seems to be due to inaccuracy in the standard Gibbs free energy data given in the literature.

\section{Fluoride System}

It has been well understood that fluoride readily complexes with rare earth elements [6,29]. The $\mathrm{pKa}$ value of $\mathrm{HF} / \mathrm{F}^{-}$is 3 as seen in Table 1 and, therefore, the relevant equations governing the precipitation of REEs with fluoride should be formulated in such a way that HF is the precipitant at $\mathrm{pH}$ less than 3 and $\mathrm{F}^{-}$should be used at higher $\mathrm{pHs}$. For example, the precipitation of $\mathrm{ReCl}_{2}{ }^{+}$with fluoride is described by Equation (8) when the $\mathrm{pH}$ of the solution is 6 or 4, while Equation (9) is for $\mathrm{pH}$ 2 and 1 . Here too, the concentration of the precipitant is assumed to be $10^{-4} \mathrm{M}$. The precipitation of the complexed REEs is remarkable as in the case with the carbonate system. Most of REEs is easily complexed with chloride, nitrate, and sulfate as long as the concentration of these anions is more than $0.1 \mathrm{M}$, below which they remain as $\operatorname{Re}^{3+}[14,15]$.

$$
\begin{gathered}
\left\{\operatorname{Re}^{3+}\right\}+3\left\{\mathrm{~F}^{-}\right\}=<\operatorname{ReF}_{3}> \\
\left\{\operatorname{Re}^{3+}\right\}+3\{\mathrm{HF}\}=<\operatorname{ReF}_{3}>+3\left\{\mathrm{H}^{+}\right\} 9
\end{gathered}
$$

Figure 2a-d present the precipitation of $\operatorname{Re}^{3+}, \mathrm{ReCl}_{2}{ }^{+}, \operatorname{Re}\left(\mathrm{NO}_{3}\right)_{2}{ }^{-}$, and $\operatorname{Re}\left(\mathrm{SO}_{4}\right)_{2}{ }^{-}$with fluoride, respectively. With regard to Figure 2a, there appears to be only one line representing pH 6 and 4 . This is because when $\mathrm{pH}$ is above $3, \mathrm{~F}^{-}$is responsible for the precipitation reaction as seen in Equation (7), in which the precipitation becomes independent of $\mathrm{pH}$. As seen in these figures, fluoride is a more powerful precipitant for REEs than carbonate in the $\mathrm{pH}$ range considered in this study.

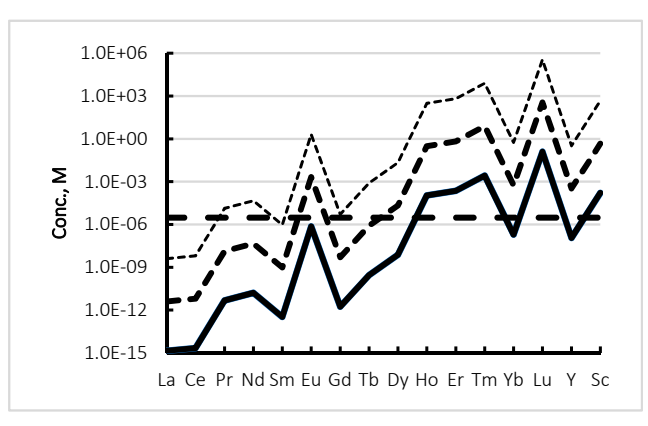

(a)

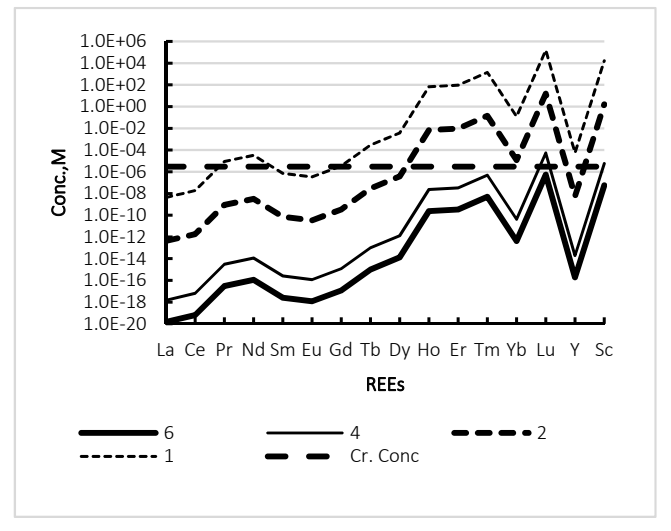

(c)

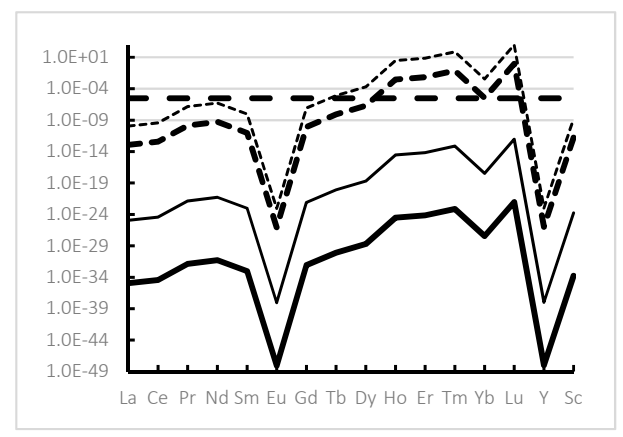

(b)

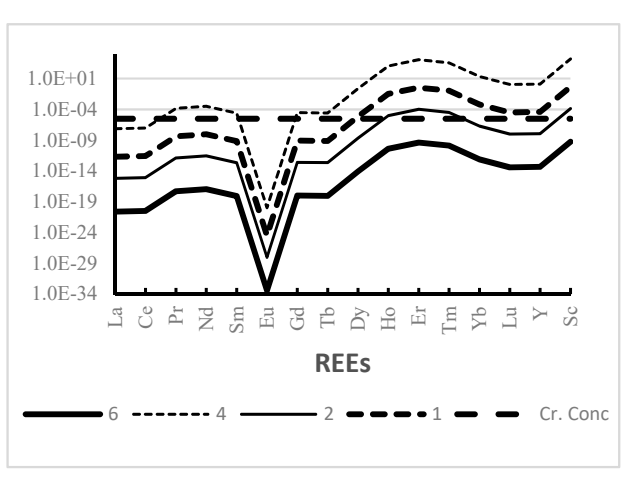

(d)

Figure 2. Concentrations of (a) $\mathrm{Re}^{3+}$, (b) $\mathrm{ReCl}_{2}{ }^{+}$, (c) $\operatorname{Re}\left(\mathrm{NO}_{3}\right)_{2}{ }^{+}$, and (d) $\operatorname{Re}\left(\mathrm{SO}_{4}\right)_{2}{ }^{-}$in equilibrium with fluoride precipitate with $10^{-4} \mathrm{M}$ of total concentration of fluoride in solution at $\mathrm{pH} 6,4,2$, and 1 . Cr. Concentration: 1 ppm line as a target concentration. 


\section{Phosphate System}

When phosphoric acid, $\mathrm{H}_{3} \mathrm{PO}_{4}$ is placed in water, it dissociates into dihydrogen phosphate, $\mathrm{H}_{2}\left(\mathrm{PO}_{4}\right)^{-}$, hydrogen phosphate, $\mathrm{H}\left(\mathrm{PO}_{4}\right)^{2-}$, or phosphate ion, $\mathrm{PO}_{4}{ }^{3-}$ depending upon the $\mathrm{pH}$ of the solution. The $\mathrm{pKa}$ values of these conjugated species are 2.1 for $\mathrm{H}_{3} \mathrm{PO}_{4} / \mathrm{H}_{2} \mathrm{PO}_{4}{ }^{-}, 7.2$ for $\mathrm{H}_{2} \mathrm{PO}_{4}{ }^{-} / \mathrm{HPO}_{4}{ }^{2-}$, and 12.0 for $\mathrm{HPO}_{4}{ }^{2-} / \mathrm{PO}_{4}{ }^{3-}$ as noted in Table 1. Therefore, the relevant equilibrium equations for the precipitation of REEs with phosphate should involve phosphoric acid for $\mathrm{pH} 1$ and 2, and dihydrogen phosphate for $\mathrm{pH} 4$ and 6. These are shown in Equations (10) and (11), respectively, for precipitation of $\mathrm{ReCl}_{2}{ }^{+}$.

$$
\begin{aligned}
& \left\{\mathrm{ReCl}_{2}{ }^{+}\right\}+\mathrm{H}_{2} \mathrm{PO}_{4}{ }^{-}=<\mathrm{RePO}_{4}>+2\left\{\mathrm{Cl}^{-}\right\}+2\left\{\mathrm{H}^{+}\right\} \\
& \left\{\mathrm{ReCl}_{2}{ }^{+}\right\}+\left\{\mathrm{H}_{3} \mathrm{PO}_{4}\right\}=<\mathrm{RePO}_{4}>+2\left\{\mathrm{Cl}^{-}\right\}+3\left\{\mathrm{H}^{+}\right\}
\end{aligned}
$$

Figure 3 illustrates the precipitation of $\mathrm{Re}^{3+}, \mathrm{ReCl}_{2}{ }^{+}, \mathrm{Re}\left(\mathrm{NO}_{3}\right)_{2}{ }^{-}$and $\operatorname{Re}\left(\mathrm{SO}_{4}\right)_{2}{ }^{-}$with phosphate. Unlike the carbonate but similar to fluoride systems, the phosphate system shows a powerful precipitation behavior even for free REEs. REEs are readily precipitated for all forms of rare earth element ions in solution except Re-chloride complexes. Here again, the unusual behavior shown by europium is most likely due to erratic thermodynamic data given in the literature. It should be noted that industrially important REE-bearing minerals are monazite and xenotime, both of which are phosphate compounds. Chemical interaction between REEs and phosphate has been investigated in numerous studies [30,31].

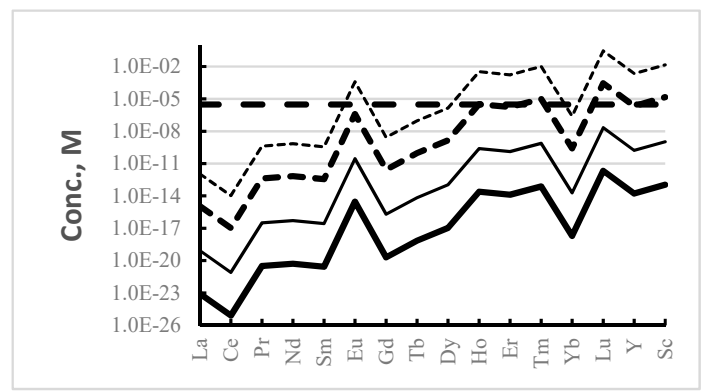

(a)

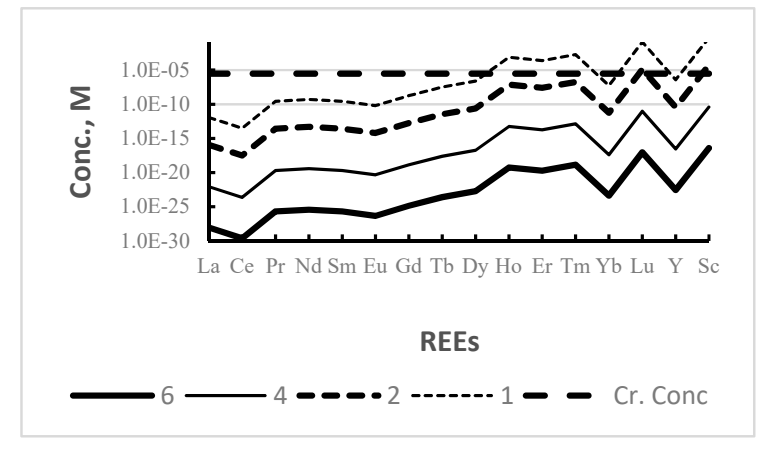

(c)

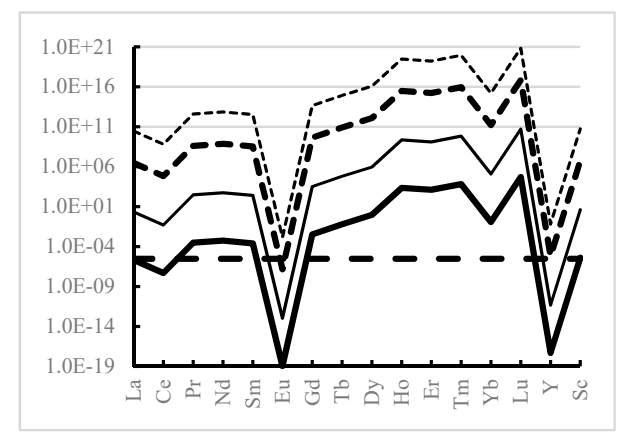

(b)

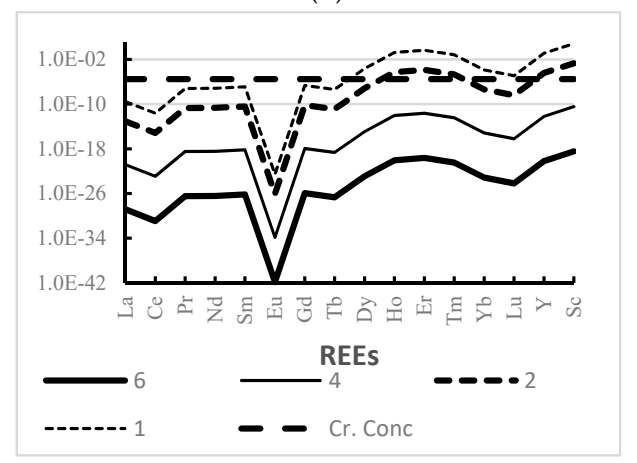

(d)

Figure 3. Concentrations of (a) $\operatorname{Re}^{3+},(\mathbf{b}) \mathrm{ReCl}_{2}{ }^{+}$, (c) $\operatorname{Re}\left(\mathrm{NO}_{3}\right)_{2}{ }^{+}$, and (d) $\operatorname{Re}\left(\mathrm{SO}_{4}\right)_{2}{ }^{-}$in equilibrium with phosphate precipitate with $10^{-4} \mathrm{M}$ of total concentration of phosphate in solution at $\mathrm{pH} 6,4,2$, and 1 . Cr. Concentration: 1 ppm line as a target concentration. 


\section{Sulfate System}

\subsection{Sulfate $\left(\mathrm{SO}_{4}{ }^{2-}\right)$}

The precipitation of REEs with sulfate is given in Figure 4. In Figure 4a, the concentration of free REEs in solution in equilibrium with Re-sulfate precipitates is shown. In the construction of this figure, Equations (12) and (13) were used. Equation (12) was used for pH 6 and 4, while Equation (13) was used for $\mathrm{pH} 2$ and 1. As mentioned earlier, the concentration of precipitants was kept constant at $10^{-4}$ M. At pH 6, the concentration of sulfate ion is $10^{-4} \mathrm{M}$ plus $10^{-6} \mathrm{M}$, in which the first was added by the rule and the latter was from sulfuric acid to adjust the $\mathrm{pH}$. In addition, at $\mathrm{pH} 4$, on the other hand, the concentration of sulfate ion is $2 \times 10^{-4} \mathrm{M}$, because of the added sulfate plus sulfate provided by sulfuric acid to adjust the $\mathrm{pH}$ of the solution. The same is also applicable for Figure $4 \mathrm{~d}$, in which case, Equations (14) and (15) were used instead of Equations (12) and (13).

It is noted that the precipitation is better at low pHs, namely $\mathrm{pH} 2$ and 1, compared to those at $\mathrm{pH}$ 6 and 4 . The reason for this is because there is more sulfate present at low pHs due to the supply of sulfate via sulfuric acid to adjust the $\mathrm{pH}$ of the solution.

$$
\begin{gathered}
2\left\{\operatorname{Re}^{3+}\right\}+3\left\{\mathrm{SO}_{4}{ }^{2-}\right\}=<\operatorname{Re}_{2}\left(\mathrm{SO}_{4}\right)_{3}> \\
2\left\{\operatorname{Re}\left(\mathrm{SO}_{4}\right)_{2}{ }^{-}\right\}=<\operatorname{Re}_{2}\left(\mathrm{SO}_{4}\right)_{3}>+\left\{\mathrm{SO}_{4}{ }^{2-}\right\} \\
2\left\{\operatorname{Re}\left(\mathrm{SO}_{4}\right)_{2}{ }^{-}\right\}=<\operatorname{Re}_{2}\left(\mathrm{SO}_{4}\right)_{3}>+\left\{\mathrm{SO}_{4}{ }^{2-}\right\} \\
2\left\{\operatorname{Re}\left(\mathrm{SO}_{4}\right)_{2}{ }^{-}\right\}+\left\{\mathrm{H}^{+}\right\}=<\operatorname{Re}_{2}\left(\mathrm{SO}_{4}\right)_{3}>+\left\{\mathrm{HSO}_{4}{ }^{-}\right\}
\end{gathered}
$$

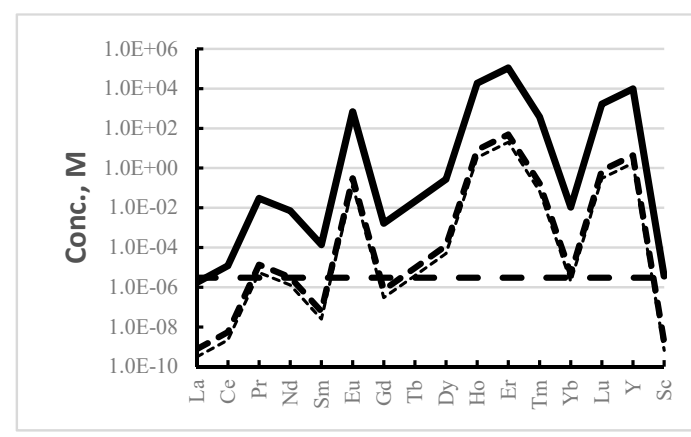

(a)

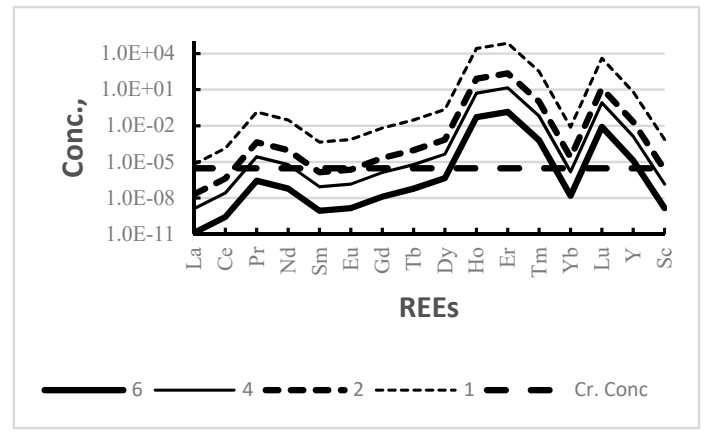

(c)

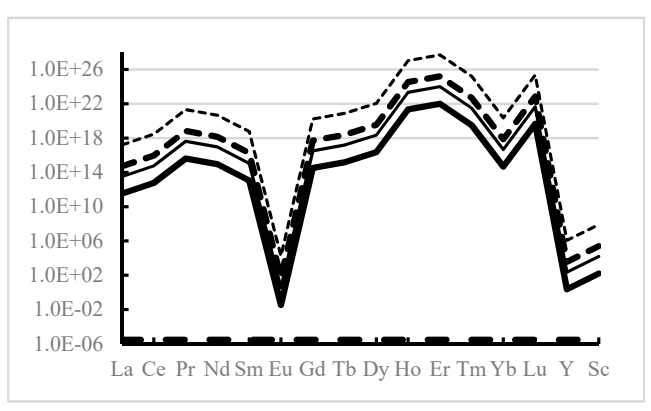

(b)

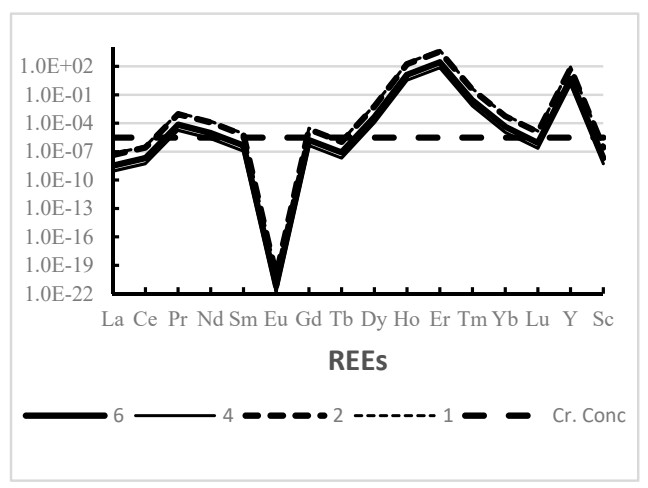

(d)

Figure 4. Concentrations of (a) $\mathrm{Re}^{3+}$, (b) $\operatorname{ReCl}_{2}{ }^{+}$, (c) $\operatorname{Re}\left(\mathrm{NO}_{3}\right)_{2}{ }^{+}$, and (d) $\operatorname{Re}\left(\mathrm{SO}_{4}\right)_{2}{ }^{-}$in equilibrium with sulfate precipitate with $10^{-4} \mathrm{M}$ of total concentration of sulfate in solution at $\mathrm{pH} 6,4,2$, and 1 . Cr. Concentration: $1 \mathrm{ppm}$ line as a target concentration. Additional sulfate is provided by sulfuric acid in (a) and (d). 
For the precipitation of $\operatorname{Re}\left(\mathrm{SO}_{4}\right)_{2}{ }^{-}$using sulfate, the precipitation calculations were done using Equations (14) and (15). The precipitation of $\operatorname{Re}\left(\mathrm{SO}_{4}\right)_{2}{ }^{-}$with sulfate is unusual in that the species does not need any precipitant but it has to release one sulfate or bisulfate to form the precipitate $<\operatorname{Re}_{2}\left(\mathrm{SO}_{4}\right)_{3}>$ as seen in Equations (14) and (15). Such precipitation can be referred to as a decomposition precipitation.

It should be noted that in practice, REEs are usually precipitated with double salt sulfate [5,32], since the precipitation is more effective with double sodium sulfate. However, in this study, precipitation of REEs with only sulfate was carried out. Although double salt sulfate precipitation is more powerful than simple sulfate precipitation, the precipitation behavior of the two systems is expected to be very similar.

\subsection{Octa-Hydrated Sulfate $\left(\mathrm{SO}_{4} \cdot 8 \mathrm{H}_{2} \mathrm{O}\right)$}

The chemical precipitation of REEs with sulfate to form octa-hydrated sulfate is very similar to the precipitation behavior of sulfate. The relevant equations used in this analysis are given in Equations (16)-(19).

$$
\begin{gathered}
2\left\{\mathrm{Re}^{3+}\right\}+3\left\{\mathrm{SO}_{4}{ }^{2-}\right\}+8\left\{\mathrm{H}_{2} \mathrm{O}\right\}=<\mathrm{Re}_{2}\left(\mathrm{SO}_{4}\right)_{3} \cdot 8 \mathrm{H}_{2} \mathrm{O}> \\
2\left\{\mathrm{Re}^{3+}\right\}+3\left\{\mathrm{HSO}_{4}{ }^{-}\right\}+8\left\{\mathrm{H}_{2} \mathrm{O}\right\}=<\operatorname{Re}_{2}\left(\mathrm{SO}_{4}\right)_{3} \cdot 8 \mathrm{H}_{2} \mathrm{O}>+3\left\{\mathrm{H}^{+}\right\} \\
2\left\{\operatorname{Re}\left(\mathrm{SO}_{4}\right)_{2}{ }^{-}\right\}+8\left\{\mathrm{H}_{2} \mathrm{O}\right\}=<\mathrm{Re}_{2}\left(\mathrm{SO}_{4}\right)_{3} \cdot 8 \mathrm{H}_{2} \mathrm{O}>+\left\{\mathrm{SO}_{4}{ }^{2-}\right\} \\
2\left\{\operatorname{Re}\left(\mathrm{SO}_{4}\right)_{2}{ }^{-}\right\}+\left\{\mathrm{H}^{+}\right\}+8\left\{\mathrm{H}_{2} \mathrm{O}\right\}=<\mathrm{Re}_{2}\left(\mathrm{SO}_{4}\right)_{3} \cdot 8 \mathrm{H}_{2} \mathrm{O}>+\left\{\mathrm{HSO}_{4}{ }^{-}\right\}
\end{gathered}
$$

As in the case with the sulfate system, the appearance of sulfate or bisulfate is based on the $\mathrm{pH}$ of the solution. In other words, when the $\mathrm{pH}$ of the system is greater than 2 , sulfate is the predominant species and at low pHs, bisulfate should be used as shown in Table 3. It was expected that the octa-hydrated system is favored in the chemical precipitation compared to simple sulfate precipitation [14,15]. However, the results shown in Figure 4; Figure 5 show that the two systems behave very similarly.

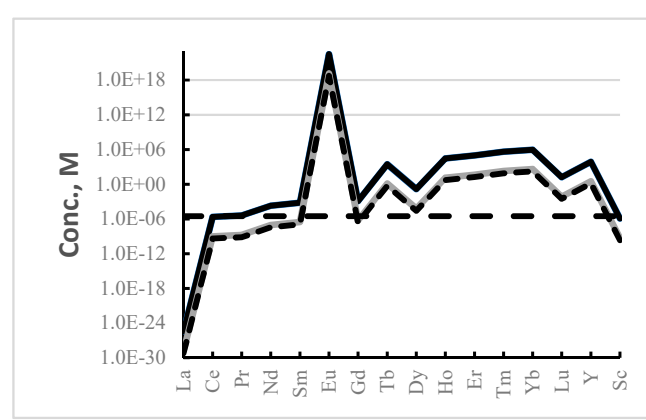

(a)

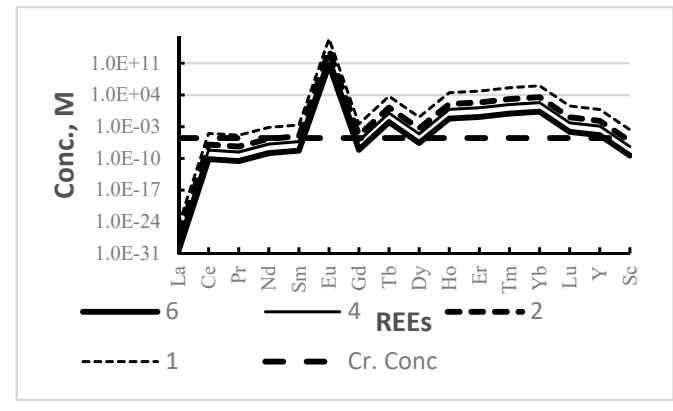

(c)

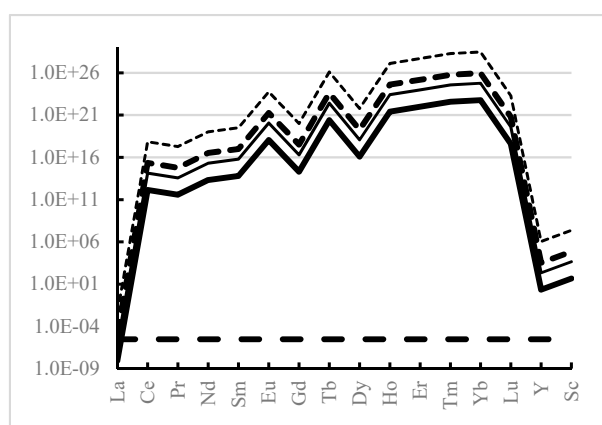

(b)

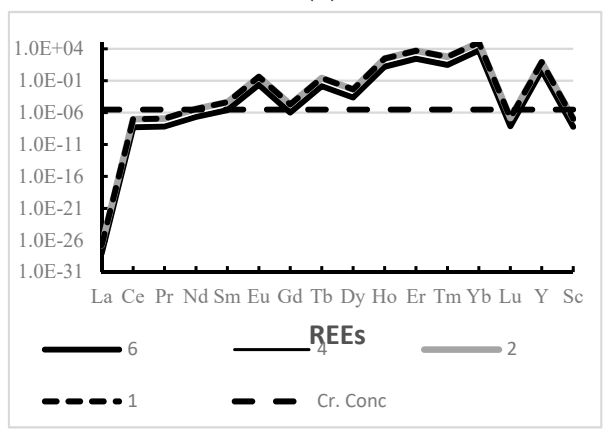

(d)

Figure 5. Concentrations of (a) $\operatorname{Re}^{3+},(\mathbf{b}) \mathrm{ReCl}_{2}{ }^{+}$, (c) $\operatorname{Re}\left(\mathrm{NO}_{3}\right)_{2}{ }^{+}$, and (d) $\operatorname{Re}\left(\mathrm{SO}_{4}\right)_{2}{ }^{-}$in equilibrium with octa-hydrated sulfate precipitate with $10^{-4} \mathrm{M}$ of total concentration of sulfate in solution at $\mathrm{pH} 6,4$, 2, and 1. Cr. Concentration: $1 \mathrm{ppm}$ line as a target concentration. Additional sulfate is provided by sulfuric acid in (a) and (d). 


\section{Oxalic Acid}

Oxalic acid is the most commonly used precipitant for REEs from solution and the majority of investigators have used this precipitant to separate REEs in the solution from other dissolved ions. This is because oxalic acid has in general a very favorable affinity with REEs in general $[4,6,9,13]$. As seen in Table 1 , the pKa values are 1 and 4.2 for $\mathrm{H}_{2} \mathrm{C}_{2} \mathrm{O}_{4} / \mathrm{HC}_{2} \mathrm{O}_{4}{ }^{-}$and $\mathrm{HC}_{2} \mathrm{O}_{4}{ }^{-} / \mathrm{C}_{2} \mathrm{O}_{4}{ }^{2-}$, respectively. As a result, the relevant equations to be used to solve the equilibrium concentrations of REEs in solution after precipitation are Equations (20) and (21) for $\mathrm{pH} 6$ and 4, and Equation (22) for $\mathrm{pH} 2$ and 1, respectively.

$$
\begin{gathered}
2\left\{\operatorname{Re}\left(\mathrm{SO}_{4}\right)_{2}\right\}+3\left\{\mathrm{C}_{2} \mathrm{O}_{4}{ }^{2-}\right\}=<\operatorname{Re}_{2}\left(\mathrm{C}_{2} \mathrm{O}_{4}\right)_{3}>+4\left\{\left(\mathrm{SO}_{4}\right)^{2-}\right\} \\
2\left\{\operatorname{Re}\left(\mathrm{SO}_{4}\right)_{2}{ }^{-}\right\}+3\left\{\mathrm{HC}_{2} \mathrm{O}_{4}{ }^{-}\right\}=<\operatorname{Re}_{2}\left(\mathrm{C}_{2} \mathrm{O}_{4}\right)_{3}>+4\left\{\left(\mathrm{SO}_{4}\right)^{2-}\right\}+3\left\{\mathrm{H}^{+}\right\} \\
2\left\{\operatorname{Re}\left(\mathrm{SO}_{4}\right)_{2}{ }^{-}\right\}+3\left(\mathrm{HC}_{2} \mathrm{O}_{4}{ }^{-}\right)+\left\{\mathrm{H}^{+}\right\}=<\operatorname{Re}_{2}\left(\mathrm{C}_{2} \mathrm{O}_{4}\right)_{3}>+4\left\{\left(\mathrm{HSO}_{4}\right)^{-}\right\}
\end{gathered}
$$

The concentrations of (a) $\operatorname{Re}^{3+}$, (b) $\operatorname{ReCl}_{2}{ }^{+}$, (c) $\operatorname{Re}\left(\mathrm{NO}_{3}\right)_{2}{ }^{+}$, and (d) $\operatorname{Re}\left(\mathrm{SO}_{4}\right)_{2}{ }^{-}$in equilibrium with oxalate precipitate with $10^{-4} \mathrm{M}$ of total concentration of oxalate in solution at $\mathrm{pH} 6,4,2$, and 1 is plotted in Figure 6.

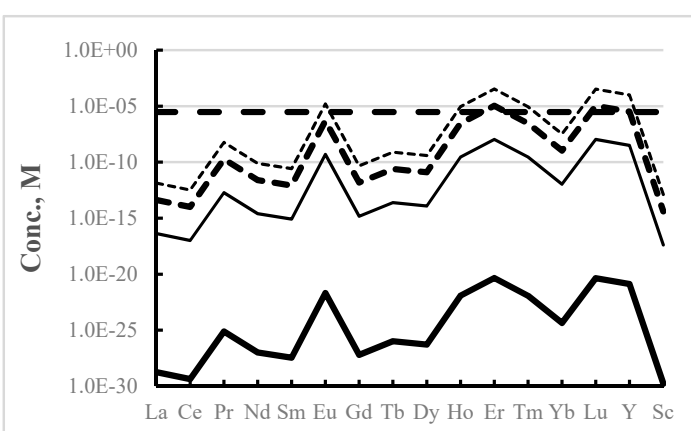

(a)

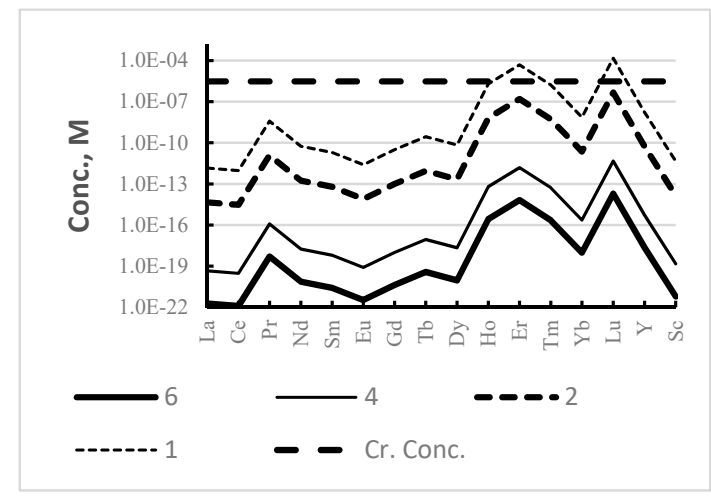

(c)

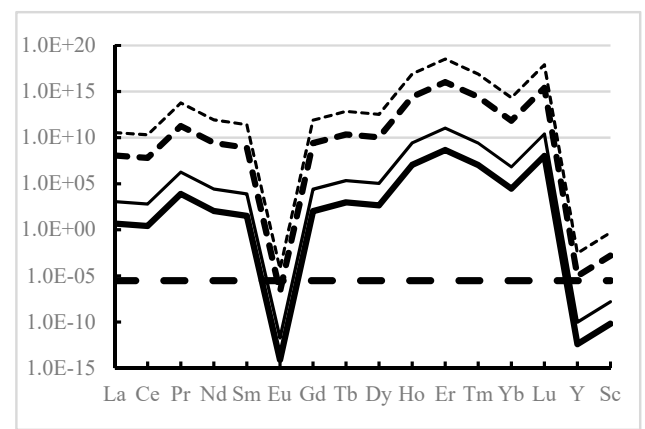

(b)

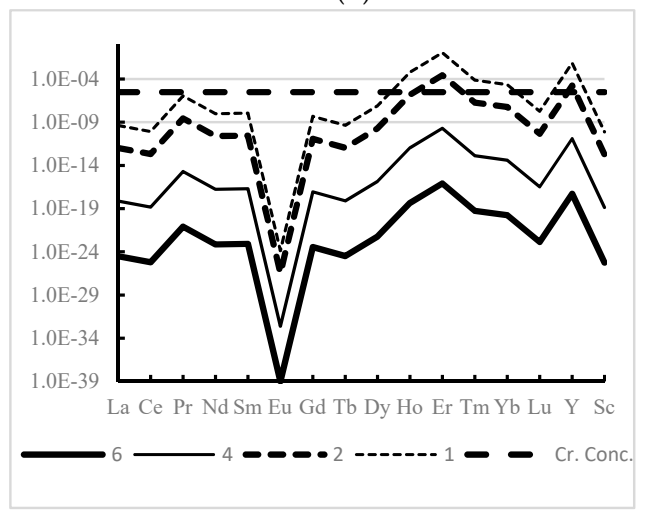

(d)

Figure 6. Concentrations of (a) $\mathrm{Re}^{3+}$, (b) $\mathrm{ReCl}_{2}{ }^{+}$, (c) $\operatorname{Re}\left(\mathrm{NO}_{3}\right)_{2}{ }^{+}$, and (d) $\operatorname{Re}\left(\mathrm{SO}_{4}\right)_{2}{ }^{-}$in equilibrium with oxalate precipitate with $10^{-4} \mathrm{M}$ of total concentration of oxalate in solution at $\mathrm{pH} 6,4,2$, and 1 . Cr. Concentration: 1 ppm line as a target concentration.

As seen in this figure, oxalic acid is proven to be the most effective precipitant for REEs in solution. The degree of precipitation is very favorable for all $\mathrm{pH}$ ranges.

\section{Comparison Among Precipitants}

As expected, all of the precipitants considered in this study have shown good precipitation characteristics. In general, the most effective precipitant is oxalate, which has shown an outstanding precipitation behavior for REEs even at low $\mathrm{pHs}$. On the other hand, most of precipitants are not effective 
unless the $\mathrm{pH}$ of the system is relatively high. As seen in Figure 7, the precipitation of free $\operatorname{Re}-i o n s, \mathrm{Re}^{3+}$ is relatively poor even at $\mathrm{pH} 6$ with the exception of oxalate and phosphate. When the $\mathrm{pH}$ of the system is low, such as pH 1 (Figure 7b), even oxalate loses its effectiveness. As seen in Figure 7, it is in general that the order of precipitation power follows: oxalate $>$ phosphate $>$ fluoride $>$ sulfate $>$ carbonate.

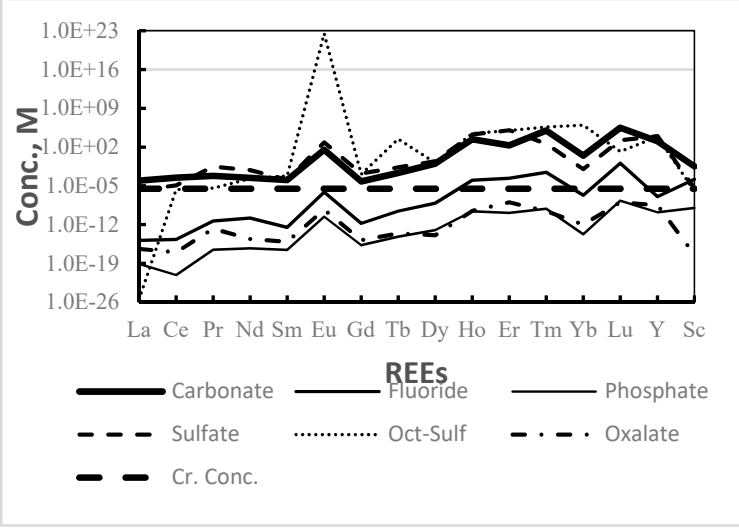

(a)

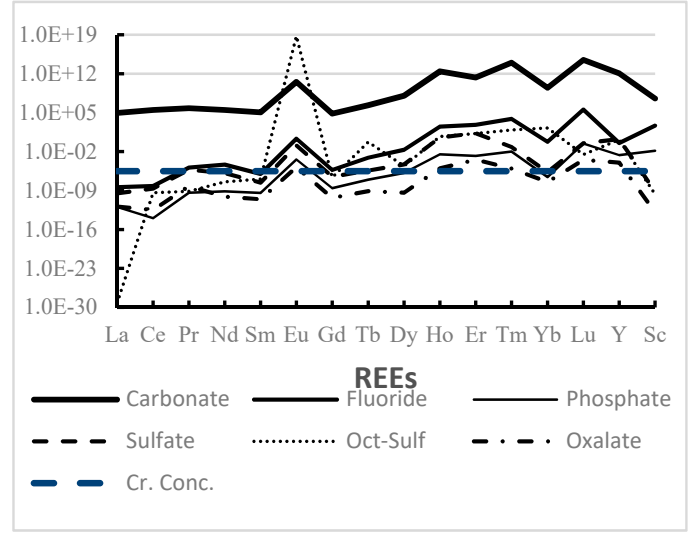

(b)

Figure 7. Concentration of $\mathrm{Re}^{3+}$ in equilibrium with various precipitants at $10^{-4} \mathrm{M}$ and at (a) $\mathrm{pH} 4$ and (b) $\mathrm{pH} 1$.

However, when REEs complex with the anions such as $\mathrm{Cl}^{-}, \mathrm{NO}_{3}{ }^{-}$, and $\mathrm{SO}_{4}{ }^{2-}$ or $\mathrm{HSO}_{4}{ }^{-}$, which almost always exist, especially at low pHs, since acids frequently used in dissolving Re-bearing minerals in the leaching operation are either $\mathrm{HCl}, \mathrm{HNO}_{3}$, or $\mathrm{H}_{2} \mathrm{SO}_{4}$. As discussed in the earlier studies [8,9], when such acids are present in the aqueous system, REEs immediately form complexes with these anions. In the presence of chloride, $\mathrm{ReCl}_{2}{ }^{+}$is the most dominating species, $\operatorname{Re}\left(\mathrm{NO}_{3}\right)_{2}{ }^{+}$for the nitrate system and $\operatorname{Re}\left(\mathrm{SO}_{4}\right)_{2}{ }^{-}$is for the sulfate system. As a result, the calculations involved to find the equilibrium concentrations of REEs should be carried out using these chemical moieties in place of $\mathrm{Re}^{3+}$. Consequently, the precipitation behavior of REEs will also change and therefore, Figure 8 will be the relevant figure in place of Figure 7 for the nitric system as an example.

It is very notable in the case of the nitrate system, the precipitation power of carbonate has overtaken that of fluoride and sulfate. Similar plots were made for the chloride system as well as the sulfate system and the results were quite similar but the intensity of precipitation was not as strong as the nitric system.

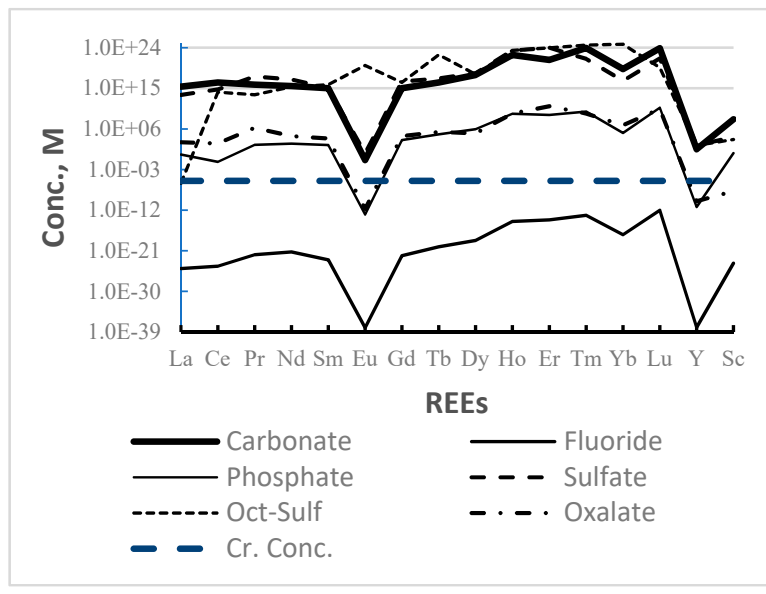

(a)

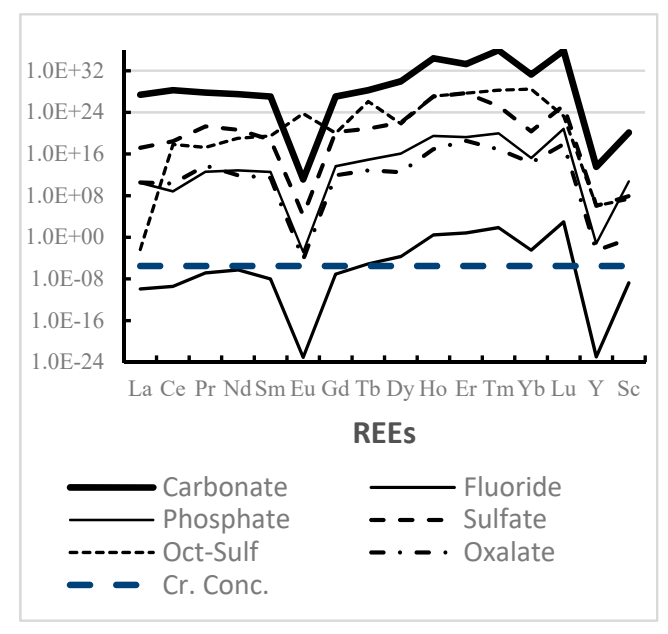

(b)

Figure 8. Concentration of $\mathrm{ReCl}_{2}{ }^{+}$in equilibrium with various precipitants at $10^{-4} \mathrm{M}$ and at (a) $\mathrm{pH} 4$ and (b) $\mathrm{pH} 1$. 


\section{Conclusions}

The chemical precipitation of REEs with precipitants including carbonate, fluoride, phosphate, sulfate, and oxalate was studied over a wide range of $\mathrm{pH}$ such as $1,2,4$, and 6 . The concentration of precipitants was fixed at $10^{-4} \mathrm{M}$ chosen as the standard concentration for comparison. Such precipitation occurs in practice after primary leaching as a part of the purification process.

With all of the five precipitants studied, Ligjt REEs tend to precipitate much easier than Heavy REEs. The effect of anions associated with acids used in the leaching process was found to have had a significant impact on the overall precipitation process. In general, the complexed REEs with these anions tend to provide a conducive environment in precipitation resulting in an order of magnitude difference in the precipitation extent. The nitrate system was found to be most effective followed by sulfate and chloride systems. The $\mathrm{pH}$ of the system has another significant factor in determining the precipitation in that the difference in pKa values of the precipitants introduces precipitant moiety of the precipitants, which has a pronounced effect on the overall precipitation.

Funding: This research received no external funding.

Acknowledgments: This paper was written in preparation of a lecture to be given at the 7th International Conference on Hydrometallurgy to be held in Ganzhou, China in May of 2020.

Conflicts of Interest: This author declares no conflict of interest in relation to this paper.

\section{References}

1. Amato, A.; Becci, I.; De Michelis, B.; Innocenzi, F.V.; Ippolito, N.M.; Gomez, P.J.; Beolchini, V.F. Sustainability analysis of innovative technologies for the rare earth elements recovery. Renew. Sustain. Energy Rev. 2019, 106, 41-53. [CrossRef]

2. Binnemans, K.; Jones, P.T.; Blanpain, B.; Gerven, T.V.; Yang, Y.; Walton, A.; Buchert, M. Recycling of rare earths: A critical review. J. Clean. Prod. 2013, 51, 1-22. [CrossRef]

3. Han, K.N.; Kellar, J.J.; Cross, W.M.; Safarzadeh, S. Opportunities and challenges for treating rare-earth elements. Geosyst. Eng. 2014, 17, 178-194. [CrossRef]

4. Gupta, C.K. Krishnamurthy. Extractive metallurgy of rare earth. Int. Mater. Rev. 1992, 37, 197-248. [CrossRef]

5. Vijayalakshmi, R.; Mishra, S.L.; Singh, H.; Gupta, C. Processing of xenotime concentrate by sulphuric acid digestion and selective thorium precipitation for separation of rare earths. Hydrometallurgy 2001, 61, 75-80. [CrossRef]

6. Yan, C.; Jia, J.; Liao, C.; Wu, S. Rare earth separation in China. Tsinghua Sci. Technol. 2006, 11, $241-247$. [CrossRef]

7. Ahmed, S.H.; Helaly, O.S.; Ghany, E. Evaluation of rare earth double sulphate precipitation from monazite leach solutions. Int. J Inorg. Bioinorg. Chem. 2015, 5, 1-8.

8. Helaly, O.S.; Abd, M.S.; Ghany, E.; Borai, E.H.; Aly, H.F.; Abded Fattan, T.M. Separation of cerium, light and heavy rare earth concentrates from Egyptian crude monazite. Chem. Technol. 2015, 10, 184-192.

9. Chi, R.; Xu, Z. A solution chemistry approach to the study of rare earth element precipitation by oxalic acid. Metall. Mater. Trans. B 1999, 30, 189-195. [CrossRef]

10. Konishi, Y.; Noda, Y. Precipitation stripping of rare-earth carbonate powders from rare-earth-loaded carboxylate solutions using carbon dioxide and water. Ind. Eng. Chem. Res. 2001, 40, 1793-1797. [CrossRef]

11. Cantrell, K.J.; Byrne, R.H. Rare earth element complexation by carbonate and oxalate ions. Geochim. Cosmochim. Acta 1987, 51, 597-605. [CrossRef]

12. Vasconcellos, M.E.; da Queiroz, C.A.; Abrao, A. Sequential separation of the yttrium-Heavy rare earths by fractional hydroxide precipitation. J. Alloys Compd. 2004, 374, 405-407. [CrossRef]

13. Khawassek, Y.M.; Eliwa, A.A.; Gawad, E.A.; Abdo, S.M. Recovery of rare earth elements from El-Sela effluent solutions. J. Radiat. Res. Appl. Sci. 2015, 8, 583-589. [CrossRef]

14. Han, K.N. Effect of anions on the solubility of rare earth element-bearing minerals in acids. In Mining, Metallurgy \& Exploration; Springer: Berlin/Heidelberg, Germany, 2019; Volume 36, pp. 215-225. [CrossRef] 
15. Han, K.N. Effect of metal complexation on the solubility of rare earth compounds. In Critical and Rare Earth Elements/Recovery from Secondary Resources; Abhilash Akcil, A., Ed.; CRC Press: Boca Raton, FL, USA, 2019; pp. 59-84.

16. Aide, M.T.; Aide, C. Rare Earth Elements: Their Importance in Understanding Soil Genesis. Int. Sch. Res. Not. 2012. [CrossRef]

17. Pourbaix, M. Atlas of Electrochemical Equilibria; National Association of Corrosion Eng: Houston, TX, USA, 1974; p. 644.

18. Dean, J.A. Lange's Handbook of Chemistry, 15th ed.; McGraw-Hill: New York, NY, USA, 1999; p. 51.

19. HSC Chemistry 5.11. Chemical Reaction and Equilibrium Software with Extensive Thermochemical Database; Version 5.0; Outokumpu Research Oy: Piori, Finland, 2002.

20. Wagman, D.D. The NBS tables of chemical thermodynamic properties: Selected values for inorganic and $\mathrm{C}_{1}$ and $\mathrm{C}_{2}$ organic substances in SI units. American chemical society and the American institute of physics for the national bureau of standards. J. Phys. Chem. Ref. Data 1982, 11, 407.

21. Kim, E.; Osseo-Asare, K. Aqueous stability of thorium and rare earth metals in monazite hydrometallurgy:Eh-pH diagrams for the systems Th-, La-, Nd-, $\left(\mathrm{PO}_{4}\right)-\left(\mathrm{SO}_{4}\right)-\mathrm{H}_{2} \mathrm{O}$ at $25^{\circ} \mathrm{C}$. Hydrometallurgy 2012, 113, 67-78. [CrossRef]

22. Firsching, F.H.; Mohammadzadel, J. Solubillty Products of the Rare-Earth Carbonates. Am. Chem. Soc. 1986, 31, 40-42.

23. Firsching, F.H.; Brune, S.N. Solubility Products of the Trivalent Rare-Earth Phosphates. J. Chem. Eng. Data 1991, 36, 93-95. [CrossRef]

24. Speddin, F.H.; Jaffe, G.S. Conductances, Solubilities and Ionization Constants of Some Rare Earth Sulfates in Aqueous Solutions at $25^{\circ}$. Inst At. Res. Dep. Chem. 1953, 76, 882-884.

25. Migdiscov, A.; Williams-Jones, A.E.; Wagner, T. An experimental study of the solubility and speciation of the rare earth elements (III) in fluoride- and chloride-bearing aqueous solutions at temperatures up to $300{ }^{\circ} \mathrm{C}$. Geochim. Cosmochim. Acta 2009, 73, 7087-7109. [CrossRef]

26. Chung, D.Y.; Kim, E.H.; Lee, E.H.; Yoo, J.Y. Solubility of rare earth oxalate in oxalic and nitric acid media. J. Ind. Eng. Chem. 1998, 4, 277-284.

27. De Vasconcellos, M.E.; da Rocha, S.M.R.; Pedreira, W.R.; da Queiroz, C.A.; Abrao, A. Solubility behavior of rare earths with ammonium carbonate and ammonium carbonate plus ammonium hydroxide: Precipitation of their peroxicarbonates. J. Alloys Compd. 2008, 451, 426-428. [CrossRef]

28. Kim, P.; Anderko, A.; Navrotsky, A.; Riman, R.E. Trends in structure and thermodynamic properties of normal rare earth carbonates and rare earth hydroxycarbonates. Minerals 2018, 8, 106. [CrossRef]

29. Tokunaga, S.; Haron, M.J.; Wasay, S.A.; Wong, K.F.; Laosangthum, K.; Uchiumi, A. Removal of fluoride ions from aqueous solutions by multivalent metal compounds. Int. J. Environ. Stud. 1995, 48, 17-28. [CrossRef]

30. Wu, S.; Zhao, L.; Wang, X.; Huang, X.; Zhang, Y.; Feng, Z.; Cui, D. Simultaneous recovery of rare earth elements and phosphorus from phosphate rock by phosphoric acid leaching and selective precipitation: Towards green process. J. Rare Earths 2019, 37, 652-658. [CrossRef]

31. Zakharova, B.; Komissarova, L.; Trasking, V.; Naumov, S.; Melnikov, P. Precipitation of Rare Earth Phosphates from $\mathrm{H}_{3} \mathrm{PO}_{4}$ Solutions. Phosphorus 1996, 111, 1-4. [CrossRef]

32. Moeller, T.; Kremers, H.E. Observations on Rare Earths Double Sodium Sulfate Precipitation for Separation of the Terbium and Yttrium Earths. Ind. Eng. Chem. Anal. 1945, 17, 44-45. [CrossRef]

(C) 2020 by the author. Licensee MDPI, Basel, Switzerland. This article is an open access article distributed under the terms and conditions of the Creative Commons Attribution (CC BY) license (http://creativecommons.org/licenses/by/4.0/). 